\title{
Józef Baniak
}

\section{"Między sekularyzacją i ewangelizacją : wartości prorodzinne w świadomości młodzieży szkół średnich", Janusz Mariański, Lublin 2003 : [recenzja]}

Ius Matrimoniale 9 (15), 283-292

2004

Artykuł został zdigitalizowany i opracowany do udostępnienia w internecie przez Muzeum Historii Polski w ramach prac podejmowanych na rzecz zapewnienia otwartego, powszechnego i trwałego dostępu do polskiego dorobku naukowego i kulturalnego. Artykuł jest umieszczony w kolekcji cyfrowej bazhum.muzhp.pl, gromadzącej zawartość polskich czasopism humanistycznych i społecznych.

Tekst jest udostępniony do wykorzystania w ramach dozwolonego użytku. 


\section{Janusz Mariański, Między sekularyzacją i ewangelizacją. Wartości prorodzinne w świadomości mlodzieży szkolnej, Lublin 2003, ss. 560, Towarzystwo Naukowe Katolickiego Uniwersytetu Lubelskiego}

Nie trzeba dziś poszukiwać „mocnych” argumentów, żeby wykazać, czym jest rodzina w życiu każdej jednostki ludzkiej, a także, jak ważną rolę ona odgrywa w życiu społecznym ludzi. Rodzina, bowiem zawsze dawała ludziom poczucie bezpieczeństwa, gwarantowała im możliwość realizacji podstawowych dążeń i potrzeb - subiektywnych i zbiorowych, jak i możliwość ekspresji własnej osobowości, pełnego jej rozwoju. Trudno wyobrazić sobie rozwój i wychowanie jednostki bez rodziny i rodziców, bez specyficznej atmosfery domu rodzinnego, bez miłości w nim przejawiającej się w wielu różnych postaciach. W rodzinie zawiązują się i kształtują podstawowe identyfikacje jednostki, jak i interakcje społeczne, w niej dziecko rozpoznaje zewnętrzny świat, uczy się nazywać rzeczy i je klasyfikować, uczy się odgrywać role społeczne, w niej też kształtuje swoje drogi życiowe. Rodzina, choć jest najmniejszą cząstką życia spotecznego, to pozostaje zarazem podstawowym lącznikiem jednostki ze społeczeństwem. Od jej wewnętrznej struktury, uznawanych w niej wartości i norm czy wzorów zachowań, zależy istotnie kształt społeczeństwa, narodu i państwa. Istotną rolę odgrywa rodzina także w życiu Kościoła poprzez swoją funkcję religijną i wychowawczą, stanowi jego strukturę elementarną, jest „domowym” Kościolem, jak uczą teologowie.

$\mathrm{Z}$ tej racji rodzinie przypisywano od dawna wielką wartość, którą pragną osiągnąć niemal wszyscy ludzie. Orientacja rodzinna jest widoczna w nastawieniach i dążeniach życiowych ludzi młodych i dorosłych, kobiet i mężczyzn. Rodzina chroni przed obcym i nieprzyjaznym światem zewnętrznym, uczy tożsamości, własnej wartości, daje poczucie satysfakcji i dowartościowania. W szczęśliwej i dającej szczęście rodzinie lokuje swój los dominujący odsetek ludzi, zwłaszcza młodych. Brak rodziny wywołuje tęsknotę i żal u ludzi, dla których jest ona z różnych względów niedostępna.

$\mathrm{Z}$ drugiej strony, rodzina napotyka też na różne utrudnienia i ma swoich przeciwników, którzy głoszą jej zanik czy „śmierć”, zniechęca- 
jąc do niej ludzi młodych. Znane są też powszechnie różne kłopoty w funkcjonowaniu rodziny w warunkach społecznych i kulturowych, doprowadzające nierzadko do jej rozpadu.

$Z$ tej racji rodzina jest przedmiotem zainteresowania uczonych reprezentujących różne nauki humanistyczne i społeczne, w tym socjologię. Literatura naukowa i popularna poświęcona rodzinie jest bardzo obszerna i ciągle wzrasta ilościowo. Socjologowie ukazują i analizują nastawienia ludzi do rodziny jako swoistej wartości i dążenia życiowego. Szczególnego znaczenia nabiera wiedza dotyczaca postaw mlodzieży wobec rodziny, do wartości prorodzinnych i z rodziny wypływających. Pewien niedosyt budzi zbyt mała liczba pogłębionych badań socjologicznych poświeconych postawom familijnym młodzieży szkolnej, jej ocenom dotyczącym wartości prorodzinnych. Badania takie winny być oparte o adekwatne teorie przemian wartości prorodzinnych i uwzględniać obecne czynniki tych przemian. Wprawdzie badań pokrewnych zrealizowano dotąd sporo, niemniej są one zbyt fragmentaryczne i nie stawiają ważnych problemów poznawczych. Dlatego ukazaną lukę zapełniają w dużym zakresie najnowsze badania socjologiczne profesora Janusza Mariańskiego, zrealizowane w kilku różnej wielkości miastach polskich wśród młodzieży szkół średnich. Wymiernym efektem tych badań jest recenzowana przeze mnie Jego książka na temat: „Między sekularyzacją i ewangelizacją. Wartości prorodzinne w świadomości młodzieży szkolnej", licząca 560 stron i podnosząca wiele newralgicznych dziś problemów z życia młodzieży, z zakresu problematyki małzeństwa i rodziny.

Warto tu zaznaczyć, iż prof. Janusz Mariański poświęcił wiele swoich prac naukowych, cennych poznawczo i odkrywczych badawczo, problematyce młodzieżowej i religijnej, czy też aksjologii młodzieżowej. Bez Jego rozpraw naukowych trudno byłoby zrozumieć i wyjaśnić problemy nurtujące ludzi młodych. Wszystkie Jego prace są niezmiernie kompetentne i cenne poznawczo. Jednak recenzowana tu praca jest specyficzna, ponieważ Autor zajmuje się w niej nastawieniem młodzieży licealnej w Polsce do malzeństwa i rodziny, do wartości z nimi związanych. Wartości prorodzinne mlodzieży, to ważny temat, który prof. Janusz Mariański ukazuje wieloaspektowo, kompetentnie i dociekliwie. Z tego względu warto ukazać dogłębniej jej treść, zwracając uwagę na jej walory poznawcze i praktyczne, z myślą o różnych czytelnikach.

Podstawę tej pracy stanowią oryginalne badania socjologiczne, które Autor zrealizował z pomocą studentów socjologii KUL w 7 mia- 
stach Polski (Jastrzębie Zdrój, Chelm, Rzeszów, Lublin, Gdańsk, Poniatowa, Ryki), obejmując nimi ogółem 2239 uczniów pierwszych i maturalnych klas liceów ogólnokształcących i technicznych. Uczniów badanych uznano jako grupę kulturową. Szkoły do badań wybierano losowo, o czym decydowało miejsce zamieszkania osoby (studenta) prowadzącej badania. Analizowane badania zrealizowano $\mathrm{z}$ pomocą ankiety audytoryjnej w salach szkolnych, a uczniom nieobecnym dostarczono ankietę indywidualnie. Badano tylko uczniów szkól publicznych trybu dziennego, o zbliżonym profilu kształcenia, zlokalizowanych w różnej wielkości miastach. Ponadto, w badaniach tych zastosowano także, jako metodę, nieustrukturalizowane wywiady z młodzieżą, mające charakter swobodnych rozmów. Bez wątpienia, zebrane w ten sposób materiały i dane empiryczne ukazują wyraziście i jasno nastawienie młodzieży licealnej do wartości prorodzinnych, jak i do samej rodziny. Ten bogaty materiał badawezy umożliwił Autorowi przygotowanie recenzowanego dzieła naukowego, złożonego $z 6$ rozdziałów tematycznych, wstępu, zakończenia, wykazu publikacji i wykazu skrótów zastosowanych w treści.

W obszernym wstępie (s. 7-24) otrzymujemy jasne tło projektu badawczego Autora, w którego świetle ukazana jest rodzina jako wartość autonomiczna i jej znaczenie w życiu ludzi; zainteresowanie małżeństwem i rodziną w różnych naukach humanistycznych, a następnie uzasadnienia wyboru tematu badań i niniejszej książki, jak i jej zakres treściowy. Autor sam zaznacza tu, że interesuje Go w szczególności świadomościowy aspekt procesu przemian rodziny i w rodzinie, $z$ wyeksponowaniem ich wymiaru normatywnego. Istotne są tu, Jego zdaniem, przede wszystkim przemiany $w$ świadomości prorodzinnej ludzi, z uwzględnieniem wartości prorodzinnych, które są uznawane przez nich za właściwe i słuszne, pozytywne i negatywne. Nie interesuje się więc Autor słusznością etyczną wartości prorodzinnych, lecz bierze pod uwage poglądy, opinie, przekonania, postawy i dyspozycje do zachowań ludzi młodych wobec małżeństwa i rodziny w określonym kontekście kulturowym: „Badamy wartości prorodzinne tak, jak jawią się w świadomości społecznej młodzieży, ze szczególnym uwzględnieniem cech społeczno-demograficznych i religijnych, sprzyjających lub nie sprzyjających ich internalizacji" (s. 22).

W pierwszym rozdziale (s. 26-139) Autor prezentuje teoretyczne zaplecze własnych badań empirycznych („Teorie przemian wartości prorodzinnych"). Mając świadomość rozlicznych teorii ujmujących kon- 
tekst społeczno-kulturowy przemian wartości prorodzinnych, Autor wybrał trafnie 3 teorie: sekularyzacji społeczeństwa i rodziny, indywidualizacji religii i rodziny, ewangelizacji. Teorie te są ukazane bardzo szeroko i precyzyjnie zanalizowane. Ten rozdzial stanowi samodzielne studium podstawowych uwarunkowań rodziny i jej wymiaru aksjologicznego. Lektura jego treści upewnia i przekonuje o szerokich i głębokich kompetencjach Autora w zakresie teoretycznej wiedzy gamologicznej i familiologicznej, wiedzy interdyscyplinarnej, aczkolwiek pozostaje On tu wytrawnym socjologiem małżeństwa i rodziny. Wiedza i mistrzowska analiza zastosowanych teorii przemian wartości prorodzinnych usatysfakcjonuje niewątpliwie wszystkich znawców tej problematyki, choć w szczególności socjologów rodziny.

W drugim rozdziale pt.: „Wartości prorodzinne jako przedmiot badań socjologicznych" (s. 141-187) Autor porusza szczegółowo 3 zagadnienia: główne tendencje przemian we współczesnej rodzinie na świecie i w Polsce; formuluje problem badań i hipotezy empiryczne; prezentuje charakterystykę demograficzno-spoleczną i religijną badanej młodzieży licealnej. Obraz rodziny współczesnej na świecie oraz kierunki i czynniki jej przemian są szkicowane precyzyjnie w oparciu o aktualną literaturę przedmiotu - obcojęzyczną i polską, a doskonałe rozeznanie Autora w aksjologii rodziny wywołuje podziw u czytelnika Jego książki. Hipotezy badawcze podnoszą znaczenie wszystkich podstawowych czynników i kryteriów świadomości prorodzinnej młodzieży szkolnej. Kryteria tych hipotez są następujące: wielkość miasta zamieszkania, płeć respondentów, typ szkoły i klasa szkolna, wierzenia i praktyki religijne. Te wszystkie czynniki wpływają na postawy młodzieży licealnej wobec rodziny i wartości $z$ nią związanych. W analizach statystycznych związków i zależności między zmiennymi Autor stosuje test niezależności i współczynnik kondyngencji „C” Pearsona. Statystyki tu stosowane są wiarygodne, poprawnie obliczone i dowodzą rzetelności metodologicznej Autora. Niezmiernie pouczające są także analizy, wsparte tabelami, cech demograficznych i społecznych oraz religijnych badanych licealistów.

Rozdział trzeci pt.: „Rodzina w ogólnym systemie wartości” (s. 189-254) ma podstawowe znaczenie $w$ tym studium i dotyczy miejsca rodziny w ogólnym systemie wartości uznawanych przez mlodzież szkolną oraz preferowanych przez nią modeli małzeństwa i rodziny. Autor omawia tu bardzo starannie poglądy i postawy swoich respondentów wobec instytucjonalnego i aksjologicznego wymiaru rodziny, a także 
ich nastawienie do małżeństwa. W rzeczy samej podnosi tu takie kwestie, jak: rodzina jako wartość naczelna oraz jej miejsce wśród wartości codziennych, problem partnerstwa w związku małżeńskim oraz modele małżeństwa uznawane wśród wartości preferowanych przez młodzież; rodzicielstwo i dzieci jako wartość docenianą przez ludzi młodych. Wyobrażenia młodzieży szkolnej na temat rodziny i małżeństwa, dostrzeganie w nich wartości podstawowych, akcentowanie roli dialogu i egalitarnych stosunków w małżeństwie i rodzinie, to bez wątpienia korzystne cechy w świadomości prorodzinnej młodych ludzi, zwłaszcza obecnie, kiedy w wielu środowiskach ludzkich podważa się zasadniczą rolę stabilnego związku małżeńskiego i trwałej wspólnoty rodzinnej. Respondenci prof. Janusza Mariańskiego ukazują, iż małżeństwo oparte na mocnych zasadach etycznych i religijnych stanowi punkt ich odniesień egzystencjalnych i może być źródłem szczęścia osobistego. Jednakże, $z$ drugiej strony, ich model małżeństwa i rodziny jest wyraźnie "przesycony” cechami nowoczesności i liberalizmu moralnego, czyli wybiega on znacznie poza ramy modelu proponowanego przez moralność religijną Kościola katolickiego. $Z$ tego też powodu studium to ukazuje się „w samą porę" i zapewne daje zarówno wielki ładunek wiedzy pozytywnej o małżeństwie i rodzinie wielu czytelnikom - młodym i dorosłym, często pozbawionym poprawnej orientacji na ten temat, jak stanowi wzór doboru i stosowania adekwatnych procedur metodologicznych w tych badaniach.

W czwartym rozdziale pt.: „Wartości prorodzinne a życie seksualne" (s. 255-313) Autor prezentuje szczegółowo i z głębokim znawstwem poglądy i postawy licealistów wobec życia seksualnego w narzeczeństwie i w malżeństwie, ich wyobrażenia o wartości seksu, jak i o warunkach inicjacji i kontynuacji pożycia seksualnego ludzi, w tym młodych. Erotyka ludzi mlodych ma dziś inny wymiar niż erotyka pokoleń starszych, $z$ reguły jest ona motywowana współczesnymi warunkami świeckości i liberalizmem etycznym. Młodzież dzisiejsza widzi w seksualności wartość odrębną i nie chce łączyć jej wyłącznie z małżeństwem i prokreacją rodzinną, nie chce też, żeby na tę sferę jej życia oddziaływał Kościół katolicki poprzez swe postulaty etyczne i religijne. Ważne znaczenie mają tu również poglądy młodzieży dotyczące znaczenia seksu w małżeństwie, jako czynnika jego zwartości, stabilności i szczęścia. Prostytucja i homoseksualizm są ważnymi, chociaż ujemnymi dziś, zjawiskami społecznymi, mającymi związek z problemami rodzinnymi. Dobrze stało się, że Autor zbadał postawy młodzieży wobec 
nich, lokując je w kontekście postaw prorodzinnych i promałżeńskich. Analizy tych zjawisk dokonane przez Autora zasługują na wysoką ocenę ze względu na dokładność, obiektywizm i szerokie spektrum uwagi.

W piątym rozdziale (s. 315-398) Autor prezentuje w świetle danych empirycznych poglądy respondentów dotyczące 2 kwestii zasadniczych, związanych bezpośrednio $z$ wartościami i normami regulującymi życie małżeńskie i rodzinne - regulację poczęć i ochronę życia ludzkiego poczętego (odpowiedzialne rodzicielstwo i życie jako wartość prorodzinna) oraz wartości decydujące o trwałości małżeństwa i spójności rodziny (stabilność związku małżeńskiego oraz wierność małżeńska). Dodatkowo otrzymujemy tu także analizę poglądów młodzieży licealnej wobec eutanazji (jako antywartości rodzinnej) oraz analizę poglądów jej na temat sakralnego wymiaru małżeństwa i rodziny, widzianego w optyce katolickiej moralności. Autor stara się tu ukazać obiektywnie wyobrażenia i oceny ludzi młodych dotyczące życia ludzkiego, miłości małżeńskiej i rodzinnej, warunków małżeństwa i rodziny, w tym akcentuje rolę czynnika religijnego. Poglądy respondentów są tu bardzo różnorodne, często odbiegające od katolickiego modelu wspólnoty małżeńskiej i rodzinnej.

Rozdział szósty pt.: „Rodzina pochodzenia jako wartość” (s. 399-481) podnosi wiele ważnych i ciekawych poznawczo kwestii i zagadnień, które są integralnymi elementami obrazu rodziny, jaki tkwi w świadomości społecznej młodzieży licealnej. Autor uwzględnił tu, co dotąd dzialo się rzadko w literaturze i $w$ innych badaniach socjologicznych, ocenę licealistów dotyczącą domu rodzinnego i rodziców, obowiązki wzajemne rodziców i dzieci, proces przekazu wartości rodzinnych w socjalizacji rodzinnej, style wychowania dzieci w domu rodzinnym oraz cele, metody i techniki ważne w ich rozwoju osobniczym. Ten rozdział, jak sądzę, stanowi bardzo znaczący i ważny wkład Autora w zbadanie i ukazanie faktycznej roli środowiska domu rodzinnego i rodziców w przygotowaniu dzieci i młodzieży do życia $w$ małżeństwie i rodzinie, widząc $w$ nim (i w innych) podstawowe ogniwo rodzinnej formacji młodych pokolen. Pełne przygotowanie młodzieży do małzeństwa i rodziny poza ramami domu rodzinnego jest praktycznie niemożliwe, a jeśli tak, to jedynie w ograniczonym zakresie. To właśnie we własnej rodzinie macierzystej, od swoich rodziców, dziewczyna i chlopiec nauczą się należytego odgrywania ról wynikających z płci, które tworzą elementarny model małżeństwa i rodziny, wzór żony i męża, matki i ojca. Oczywiście, ta swoista „lekcja” życia małzeńskiego i rodzinnego będzie możliwa jedynie w rodzinie pozytywnej, normalnie zbudowanej i funkcjonującej, opartej na 
miłości i empatii wszystkich osób ją tworzących. Za taką właśnie rodziną tęsknią ludzie młodzi, a respondenci prof. Janusza Mariańskiego są praktycznym przykładem tej tęsknoty i takich marzeń, upatrujący w niej swoje szczęście osobiste.

Czytając książkę prof. Janusza Mariańskiego, bez trudu widzimy, że współczesna młodzież szkolna, uczniowie szkół licealnych w Polsce, czyli ludzie bardzo młodzi, są pełni ideałów i marzeń życiowych, które łączą sami czy też lokują w miłości, w małżeństwie i w rodzinie, jakby na przekór ideologiom i działaniom antyrodzinnym i antymałżeńskim, nagłaśniającym zmierzch małżeństwa jako związku monogamicznego i trwałego kobiety i mężczyzny, opartego na ich wzajemnej miłości i przyjaźni, jak i upadek rodziny, jako trwałej wspólnoty uczuć ludzkich $w$ sytuacji międzypokoleniowej. Rodzina stanowi ciągle ważną i znaczącą wartość dla dominującej większości młodych ludzi obojga płci, a także wszelkie wartości z nią związane i z niej wynikające. Nie wątpię, iż recenzowana książka jest znaczącą rozprawą naukową na rynku publikacji familiologicznych i zdoła zainteresować swoją bogatą i różnorodną treścią licznych czytelników - badaczy małżeństwa i rodziny, nauczycieli wychowania rodzinnego, wychowawców młodzieży, katechetów, studentów i uczniów, choć przede wszystkim jest ona adresowana do rodziców, gdyż to oni są najbardziej odpowiedzialni za los i szczęście swoich dzieci, to oni są pierwszymi i najważniejszymi nauczycielami życia małżeńskiego i rodzinnego swoich córek i synów, mówiąc im o wartościach prorodzinnych i ucząc ich życia w matżeństwie i rodzinie przykładem własnego małżeństwa i własnej miłości. Książka ta ukazała się w „samą porę”, zapełniając głęboką lukę w wiedzy o młodzieży i o jej marzeniach o szczęśliwej rodzinie, jak i o małżeństwie jako losie dwojga ludzi połączonych z sobą trwale i z ufnością w stabilnym związku małżeńskim i rodzinnym.

Książka ta, to dzieło w całej pełni naukowe, bazujące na podstawach metodologii nauk społecznych, na głębokiej i wieloaspektowej wiedzy swego Autora, w którym widzimy jasno postawiony i ukazany problem badawczy i problematykę szczegółową. Na podkreślenie zasługuje adekwatne i głęboko ujęte podłoże teoretyczne badań empirycznych, jak i umiejętnie zastosowana metoda statystyczna, czyli statystyki hipotez, weryfikujące ich zasadność i trafność merytoryczną.

Książka ta jest pełna zalet, które już wyżej ukazałem i wysoko oceniłem. Z drugiej strony zaś odnalazłem w niej kilka usterek i braków, na które niżej zwrócę uwagę. 
Wartość nieocenioną w tym studium empirycznym ma bardzo obszerna bibliografia publikacji obcojęzycznych i polskich. Lącznie Autor wykazał w niej aż 793 pozycji, spośród których znaczny odsetek cytuje w swej książce. Bibliografia ta stanowi odrębną całość i źródło wiedzy o młodzieży, małżeństwie, rodzinie, kulturze, wychowaniu, religii, moralności, Kościele itp., o czym przekonałem się sam, studiując ją dokładnie. Na uwagę zasługuje literatura z obszaru języka niemieckiego na te tematy, a prof. Janusz Mariański jest wytrawnym jej znawcą i starannym czytelnikiem. Dołączenie tej bibliografii do treści książki oznacza wielką wartość dla niej samej, lecz także stanowi pomoc nieocenioną dla czytelników problematyki gamologicznej i familiologicznej, młodzieżowej, aksjologicznej i moralnej. Charakter recenzowanej książki jednakże domagał się uporządkowania tej bibliografii według klucza systematyzacyjnego, czyli ułożenia jej zgodnie z tematem głównym i problemami dodatkowymi na: literaturę źródłową, przedmiotu, metodologiczną i pomocniczą, a wtedy nabralaby ona innego znaczenia w całości pracy i spełniłaby lepiej i pełniej swoją funkcję informacyjną i metodologiczną. Badacze empirycy problematyki małżeńskiej, rodzinnej i młodzieżowej docenią zapewne wkład Autora w opracowanie tej bibliografii i samego dzieła naukowego, na niej opartego.

Należało zastanowić się podczas druku nad ewentualną rekonstrukcją planu książki, polegającą na przesunięciu na inne miejsca określonych rozdziałów, a w nich niektórych paragrafów. Moim zdaniem, zmiany tej domagała się logika zdarzeń analizowanych w książce, jak i kolejność ich wynikania i zazębiania się wzajemnego. Tematem pracy są „wartości prorodzinne” tkwiące w świadomości licealistów, co oznacza, iż to nimi należało zająć się tu w szczególności. W związku z tym problematyczne wydaje się obecne ulokowanie rozdziałów III i VI w calości książki. Rozdziały te, traktujące o rodzinie i o rodzinie pochodzenia w systemie aksjologicznym młodzieży badanej, powinny, moim zdaniem, być umieszczone w książce albo jako (w kolejności) III i IV, będąc punktem wyjścia analiz wartości prorodzinnych, albo jako V i VI, będąc punktem dojścia tych analiz. W rodzinie kumulują się wszystkie wartości z nią związane i z niej wynikające. Obecny układ treści książki wydaje się nieco „sztuczny” z familiologicznego punktu widzenia.

Przesunięcia były też niezbędne w treści niektórych rozdziatów książki, co w efekcie uczyniłoby ją bardziej komunikatywną w odbiorze. 
a) W obecnym rozdziale III jako 1 i 2 powinny znajdować się paragrafy 3 i 4, poświęcone małżeństwu, a dopiero po nich paragrafy traktujące o rodzinie, czyli obecne $1,2,5$. Wpierw jest bowiem malżeństwo, a później powstaje rodzina, co oznacza też porządek w analizie tych zjawisk.

b) W rozdziale IV należało przesunąć paragraf 2, poświęcony homoseksualizmowi i prostytucji, na miejsce paragrafu 3, poświęconego życiu seksualnemu w małżeństwie. Postawy licealistów wobec homoseksualizmu i prostytucji mają tu dodatkowe znaczenie. Stąd umiejscowienie ich w 3 paragrafie wydaje się zasadne i logiczne.

c) W rozdziale $\mathrm{V}$ paragraf 3 (o eutanazji) należało przesunąć na miejsce paragrafu 6 jako ostatni w tym rozdziale. Zagadnienie eutanazji, nawet postrzegane jako antywartość (a może właśnie z tej racji) rodzinna, jest tu kwestią dodatkową, więc to jego przesunięcie w planie rozdziału było zasadne i nie wpłynęłoby na osłabienie jego wartości i komunikatywności, a wręcz przeciwnie, spowodowałoby ich ulepszenie.

d) W pracy występują rozbieżności między numeracją stron w spisie i w jej treści. Różnice te utrudniają czytelnikowi swobodną lekturę książki. Uchybienie to jest niedopatrzeniem korektorskim redakcji, a nie Autora książki.

Wskazane usterki i błędy w niczym nie umniejszają ogólnej wartości naukowej, metodologicznej i pragmatycznej tej książki. Wartość ta pozostaje nadal bardzo wysoka, wywołując równie wysoką jej ocenę recenzenta. Sugestie zmian lub innego ujęcia mają na względzie wylącznie jeszcze większą jej wartość z każdego punktu widzenia.

W konkluzji końcowej chcę wyraźnie zaznaczyć, że recenzowana książka prof. Janusza Mariańskiego pt.: „Wartości prorodzinne w świadomości młodzieży szkolnej" stanowi novum w literaturze przedmiotu, zaś prezentowane na jej łamach wyniki badań socjologicznych są unikatowe i dają calkiem odmienne od dotychczasowego światło na nastawienie młodzieży licealnej w Polsce do małzeństwa, rodziny, miłości, nie wyłączając żadnej ich cechy i funkcji. Profesor Janusz Mariański ukazuje się czytelnikowi kolejny raz jako bardzo kompetentny socjolog młodzieży, a jednocześnie jako socjolog małżeństwa i rodziny. Nie watpię, iz fachowcy od problematyki rodzinnej i młodzieżowej docenią najwyżej wartość tej książki, zarówno naukowo-poznawczą, jak i czysto egzystencjalną. Książka ta, to głębokie źródło wiedzy o młodzieży i o jej poglądach i postawach wobec wartości pro- 
rodzinnych, ale i moralnych i religijnych, silnie złączonych $z$ duchem obecnego czasu.

Gratulacje należą się także Towarzystwu Naukowemu KUL za wolę wydania drukiem tej książki, dziś tak potrzebnej i oczekiwanej w Polsce. Należy mieć nadzieję, iż książka ta będzie dostępna dla wszystkich zainteresowanych tematyką, jaką Autor zaprezentował tak kompetentnie i pięknym, zrozumiałym językiem.

Józef Baniak 